\title{
ResearchArticle
}

\section{Correlation and path analysis for yield, yield attributes and shoot and fruit borer tolerance in brinjal (Solanum melongena L.)}

\author{
G. SAMLINDSUJIN*, P. KARUPPAIAH, K. MANIVANNAN AND K. SARAVANAN
}

\begin{abstract}
SUMMARY
The present investigation was carried out in the Department of Horticulture, Faculty of Agriculture, Annamalai University, during the period 2014 - 2015 to asses the correlation and path co-efficient analysis of 60 genotypes of brinjal for yield and shoot and fruit borer tolerance. The experiment was laid out in Randomized Block Design with three replications. Among the sixteen morphological characters studied, number of long styled flowers per plant (8.803), number of short styled flowers per plant (5.403), number of fruits per plant (3.099), fruit weight (0.757), days to first harvesting (0.133) and shoot and fruit borer incidence (0.082) showed positive direct effect in path co-efficient analysis. Positive correlation was recorded for fruit weight (0.885), fruit girth (0.644) and number of fruits per plant $(0.622)$. Therefore, these characters are important which may be included in selection criteria for improvement in fruit yield per plant as well as tolerance to shoot and fruit borer incidence.
\end{abstract}

Key Words : Brinjal, Correlation, Direct and indirect effects, Path analysis, Shoot and fruit borer tolerance

How to cite this article : Samlindsujin, G., Karuppaiah, P., Manivannan, K. and Saravanan, K. (2016). Correlation and path analysis for yield, yield attributes and shoot and fruit borer tolerance in brinjal (Solanum melongena L.). Internat. J. Plant Sci., 11 (2): 187-192, DOI: 10.15740/HAS/IJPS/11.2/187-192.

Article chronicle : Received : 15.02.2016; Revised : 07.04.2016; Accepted : 21.05.2016

\section{MEMBERS OF THE RESEARCH FORUM}

Author to be contacted :

G. SAMLINDSUJIN, Department of Horticulture, Faculty of Agriculture, Annamalai University, Annamalai Nagar, CHIDAMBARAM (T.N.) INDIA

Email: samlindsujin@gmail.com

Address of the Co-authors:

P. KARUPPAIAH AND K. MANIVANNAN, Department of Horticulture, Faculty of Agriculture, Annamalai University, Annamalai Nagar, CHIDAMBARAM (T.N.) INDIA

K. SARAVANAN, Department of Genetics and Plant Breeding, Faculty of Agriculture, Annamalai University, Annamalai Nagar, CHIDAMBARAM (T.N.) INDIA 